\title{
東日本大震災とジャーナリストの惨事ストレス（3）
}

一被災地内新聞社への質問紙調査からみた取材・報道活動と心身の自覚症状一注 1

福岡欣治 ${ }^{1} \cdot$ 高橋尚也 $^{2} \cdot$ 松井豊 $^{3} \cdot$ 安藤清志 $^{4} \cdot$ 井上果子 $^{5} \cdot$ 畑中美穂 ${ }^{6}$

$\left({ }^{1}\right.$ 川崎医療福祉大学医療福祉マネジメント学部・ ${ }^{2}$ 立正大学心理学部・ ${ }^{3}$ 筑波大学人間総合科学研究科・ ${ }^{4}$ 東洋大学社会学部・ ${ }^{5}$ 横浜国立 大学教育人間科学部・ ${ }^{6}$ 名城大学人間学部)

キーワード: 東日本大震災, 惨事ストレス，新聞ジャーナリスト

\section{The Tohoku Earthquake and critical incident stress of journalists (3): Coverage and news reporting activities and subjective symptoms from Questionnaire survey with newspaper companies in the disaster area}

Yoshiharu FUKUOKA $^{1}$, Naoya TAKAHASHI ${ }^{2}$, Yutaka MATSUI ${ }^{3}$, Kiyoshi ANDO ${ }^{4,}$ Kako INOUE $^{5}$, and Miho HATANAKA ${ }^{6}$

$\left({ }^{1}\right.$ Kawasaki University of Medical Welfare, ${ }^{2}$ Rissho University, ${ }^{3}$ University of Tsukuba, ${ }^{4}$ Toyo University, ${ }^{5}$ Yokohama National University, ${ }^{6}$ Meijo University)

Key words: Tohoku Earthquake, Critical incident stress, Newspaper journalists

\section{問題と目的}

職務上の惨事ストレスに関寸る研究は, 従来, 消防職員等を 中心におこなわれてきた（松井，2005）。しかし，災害や事故 等の取材・報道にあたるジャーナリストもまた惨事に触れ, 時 には長く関わりをもつことになる。2011 年 3 月 11 日に発生し た東日本大震災でも，災害の惨状とその後の被災地，被災者の 様子を広く社会に伝えるために,多くの活動が積み重ねられて きた。そして，この大震災にかかわる取材・報道そして編集等 の活動の中で, 強いストレス症状をもつに至ったジャーナリス 卜の存在が，いくつかの報道やジャーナリスト自身の手記，そ して面接調査(福岡他, 2012) からも浮き彫りにされつつある。

本報告では, 東日本大震災の被災地域を日常の取材エリアに 含む複数の地方新聞社に所属するジャーナリストを対象とし て震災発生の約 1 年後におこなわれた質問紙調查にもとづき, 東日本大震災にかかわる取材・報道を通じたジャーナリストの 体験と抱えた問題, そして活動直後から 1 ケ月間での心身の自 覚症状等について報告する。

\section{調査方法}

\section{方 法}

職場を通じた配布および個別郵送回収による質問紙調査(無 記名)。実施時期は 2012 年 2 月上旬から 3 月。

\section{調査対象}

東日本大震災で直接の被害を受けた東北および関東地方の 計 5 県（宮城, 岩手等）にそれぞれ本拠をもつ地元新聞社に勤 務するャーナリスト (記者, カメラマン, 編集者等)。配布 270 部, 回収 120 部（有効回答 $44.4 \%$ )。

\section{調査内容}

東日本大震災発生後の取材・報道活動の開始時期, 自らかか わった取材・報道事案の特徵, 取材対象との関係や取材現場で の活動および報道内容に関する問題, 震災取材・報道にかかわ る職場・組織としての問題, 活動開始から 1 ケ月間での心身の 自覚症状など。なお，項目の作成にあたっては畑中他（2009） を参照しつつ, 東日本大震災後の面接調査等で得られた情報を 加味した。具体的な内容は適宜結果の項を参照。

\section{回答者の基本属性}

結 果

男性 $83.3 \%$ ・女性 $16.7 \%$, 年代は 20 代 $30.0 \%$ ・30 代 $40.3 \%$ ・ 40 代 $28.3 \%$ 等であった。震災発生時の職位は, 記者 $68.3 \%$ ・ カメラマン $10.8 \%$ ・支局長 $5.8 \%$ 等であった。若手から中堅の 男性記者・カメラマンが回答者の中心であるといえる。

\section{取材・報道事案の特徴}

計 15 項目に対して該当する特徴を選択してもらったところ, 9 割近い回答者が地震あるいは津波被害の現場や被災者の目
前, また余震の危険を感じながらの取材・報道活動をおこなっ ていた。放射線被害の危険下での取材経験者も $35.0 \%$ みられた。 $57.5 \%$ は地震あるいは津波の被害を受けつつある様子」を直 に目撃しており, 遺体を目撃した人も $30.0 \%$, 震災以前からの 取材対象者が犠牲になったとする人も $27.5 \%$ にっていた。

\section{取材・報道活動を通じて体験した困難や問題}

肉親や知人が犠牲になった人に取材し, 取材対象者への接 し方に悩んだ人が 75\%を超えていた。63.3\%が取材対象者の話 しをつらい気持ちで聞き， $30.8 \%$ が対象者に負担をかけたり結 果的に傷つけたと感じていた。その一方で，38.3\%が過熱取材 を, $28.3 \%$ が対象者や家族のプライバシー侵害の状況を認め, $24.2 \%$ が重要な情報を他社に抜かれたと回答していた。現場に いた人から取材活動を非難された人も $40.8 \%$ にっていた。所 属する組織内で上司に現場の状況を理解してもらえなかった 人が $42.5 \%$ お，「組織の中で自分は受け入れられていたと思 う」人は $32.5 \%$ であった。

\section{活動開始直後から 1 ヶ月間における心身の自覚症状}

計 17 項目で症状の有無をたずねたところ，87.5\%は何らか の症状があったと回答していた。該当者が多かったのは「涙も

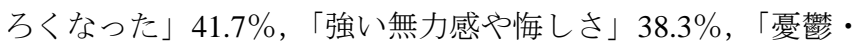
気が滅入る」 $32.5 \%$, 「無気力・疲労感」 $26.7 \%$, 「睡眠障害」 26.7\%などであった。

\section{考 察}

本研究の結果はおおむね放送ジャーナリストの結果 (福岡他, 2008）と一致していた。ただし職務ストレスにおいて「他社と の競争」が 1 つの独立した因子として抽出されなかった点は異 なっていた。また放送ジャーナリストと異なり対象者の多くは 記者であり, 職務内容による違いはみられなかった。変数間の 関連性では，上司のサポートの重要性が改めて示された。

\section{引用文献}

福岡欣治他 (2012). 東日本大震災とジャーナリストの惨事ストレス

(1) 被災地内新聞社を対象とした予備的面接調査 日本卜ラウマ ティック・ストレス学会第 11 回大会（6月発表予定）

畑中美穂他 (2009). 新聞ジャーナリストが経験する惨事の特徵とス トレス反応 横浜国立大学大学院教育学研究科教育相談 - 支援総 合センター研究論集, 9, 101-120.

松井豊 (2005). 惨事ストレスとは 松井豊(編著) 惨事ストレスー のケア ブレーン出版 pp.3-17.

注 1 : 本研究は平成 $22 \sim 25$ 年度科学研究費補助金(基盤研究 A 22243042: 代表松井豊)の助成を受けておこなわれ, 調查は日本新聞労働組合連合会 (新聞労連) の協力下で実施された。ご協力いただいた各組織ならびに 自らの体験を率直にご回答くださった方々に深く感謝します。本調查に 関しては, 立正大学大学院心理学研究科の研究倫理審査を経ている。 